\title{
"The Penguins Are Coming": Brand Mascots and Utopian Mass Consumption in Interwar Britain
}

\section{Richard Hornsey}

\begin{abstract}
This article explores the cultural dynamics of branding and mass consumption in Britain during the 1920s and 1930s. It focuses on Penguin Books' cartoon mascot, which appeared on all of the firm's paperback covers and in-store promotional material from 1935. A familiar but critically ignored cultural icon, Penguin's mascot followed a wave of prominent advertising characters that energetically burst onto Britain's commercial scene in the early 1920s. Highly visible on packaging, poster hoardings, and advertisements within the press, brand mascots became popular media stars in the 1920s, seeming to herald a dawning age of material parity and collective consumer sovereignty. A decade later, Penguin's mascot used this utopianism around branded mass consumption to forge a leftist vision of social-democratic progress. Augmented by certain in-store display techniques and modes of purchase, Penguin Books appeared to constitute an enlightened public sphere. The cartoon bird became a lucrative mechanism through which browsers were invited to contribute to this progressive cultural project.
\end{abstract}

\section{INTRODUCTION}

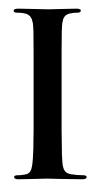

n May 1935, an enigmatic advertisement appeared in the Publishers' Circular, the leading professional journal for British booksellers (figure 1). Next to the headline "The Penguins are Coming," a procession of six crudely drawn birds slid down across a blank white space. "If you want to know what all this is about," readers were instructed, "turn over quickly to the next page." This was, of course, the official teaser for Allen Lane's new series of Penguin Books, whose inaugural ten titles, listed overleaf, would be published later in the summer to great commercial success. Produced in paperback and priced at only sixpence each, the books were sold through "variety" multiple stores and newsagents as much as via conventional bookshops. The company soon boasted that three million copies had been sold within the first twelve months- the equivalent of one book every ten seconds, or enough to create a pile five times the height of Mount Everest. ${ }^{2}$

Richard Hornsey is lecturer in Modern British History at the University of Nottingham, UK. He is the author of The Spiv and the Architect: Unruly Life in Postwar London (Minnesota, 2010). He is currently writing a book about the cultural impact of mass production on British life in the 1920s and '30s.

1 "The Penguins Are Coming" (advertisement), Publishers' Circular and the Publisher and Bookseller, 25 May 1935, 707.

${ }^{2}$ Sales notice, 5 October 1936, in Scrapbook (1935-9), DM1294/1/1, Penguin Archive, University of Bristol Library Special Collections. 


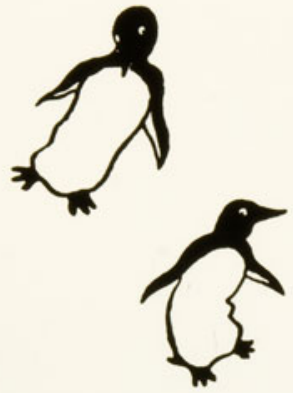

\section{THE}

\section{PENGUINS}

\section{A R E}

\section{COMING}

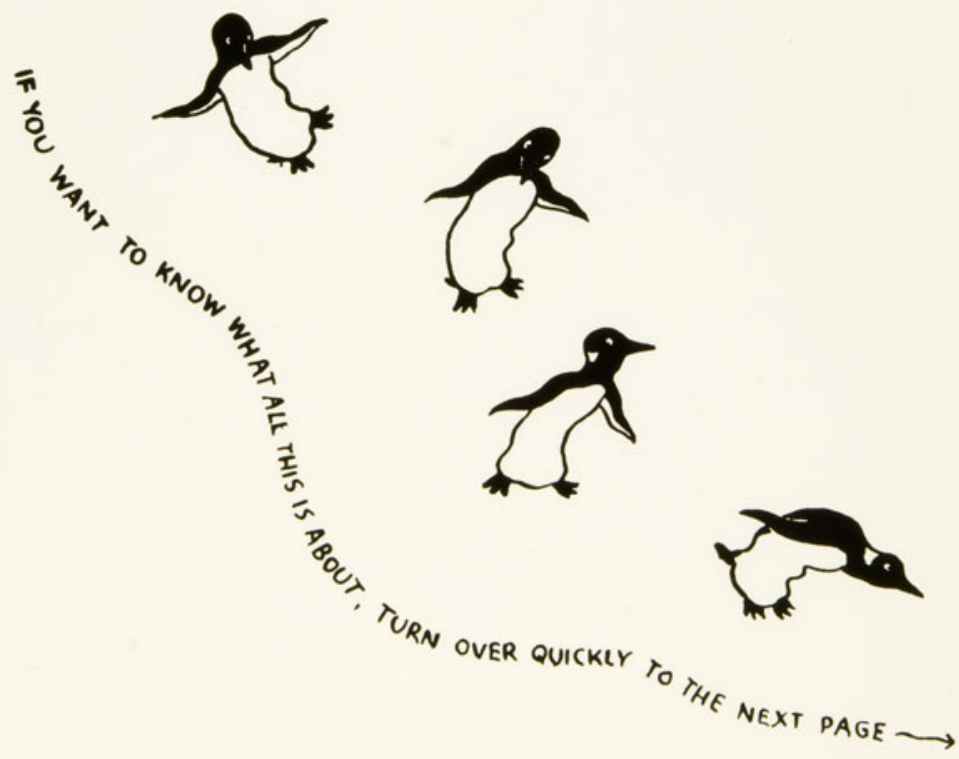

Figure 1-"The Penguins Are Coming" (first trade advertisement for Penguin Books), The Publishers' Circular and the Publisher and Bookseller, 25 May 1935, 707, in Scrapbook (1935-9), DM1294/ 1/1, Penguin Archive, University of Bristol Library Special Collections.

Sympathetic critics saw Penguin's success as a genuine portent of progressive social change. "It could hardly be disputed," wrote the publisher Harold Raymond, "that Penguins are finding a new public and training that public to like the best in modern writing."3 Similarly, for the socialist writer Margaret Cole, the new sixpennies were

${ }^{3}$ Harold Raymond, Publishing and Bookselling: A Survey of Post-War Developments and Present-Day Problems (London, 1938), 23. 
"the opening stage of a real revolution." By circumventing the expense and snobbery of ordinary bookshops, she argued, Penguin was creating a "vast new public" out of those too poor, too deprived of formal education, or too remote to frequent them. ${ }^{4}$ The popular press concurred. As one journalist wrote, "I was interested to observe in the lounge of a London hotel, within the last couple of weeks, that everyone who was reading a book and not a newspaper was deep in a 'penguin'! This is no exaggeration, and ... it just points to the fact that 'everybody is doing it'!"5

Proclamations of a new reading public had been recurrent in Britain since the 1880s, but Penguin's commentators clearly understood Lane's attempt at a socialdemocratic intervention. ${ }^{6}$ As he told the Penrose Annual in 1938, "From the moment when somebody invented a way of duplicating books from movable types, the mass-produced sixpenny became inevitable. For not only are books intrinsically perhaps the most suitable of all commercial products for mass-production methods, but it is also very important that books should be mass-produced if there is to be any meaning in liberty of opinion, and if knowledge is to be accessible to everyone."7 To further this vision, in May 1937 Lane launched a corresponding set of Pelican adult-education reprints, followed that November by the Penguin Specials, an occasional series of polemical commissions on particular current affairs. To foster a deeper sense of customer allegiance to the project, the firm issued its own free newsletter, Penguin's Progress, that kept subscribers up to date on the latest releases.

Rick Rylance has suggested that in the late 1930s, Penguin Books' readership developed into something close to an authentic public sphere. ${ }^{8}$ Yet the company never sustained the kind of grassroots participation achieved by its contemporary, the Left Book Club. ${ }^{9}$ By August 1937, the Penguin's Progress mailing list contained an impressive sixty-thousand names and addresses, but those numbers should not be mistaken for either a genuine dialogue between the company and its customers or a networked conversation among its readers. ${ }^{10}$ However, the perception that Penguin Books was establishing the conditions for enlightened debate was deeply attractive, particularly to a stratum of consciously progressive readers. In 1947, when the social research organization Mass-Observation explored the social impact of the firm, it identified what it called a definite "Penguin public." Penguin readers were found to have left-wing sympathies, to be generally educated to secondary level, and to

${ }^{4}$ Margaret Cole, Books and the People (London, 1938), 6, 38. See also Donald Kitchin, "A Revolution in Publishing," Left Review (May 1938): 970-72.

${ }^{5}$ L.H., "Penguin Books," Tenbury Wells Mail (2 May 1936), in Scrapbook (1935-9), Penguin Archive.

${ }^{6}$ Christopher Hilliard, To Exercise Our Talents: The Democratization of Writing in Britain (Cambridge, MA, 2006), 15-16. See also Sidney Dark, The New Reading Public (London, 1922); Q. D. Leavis, Fiction and the Reading Public (London, 1932); Philip Unwin, "A New Reading Public?,” Bookseller, 5 April 1934: 184.

${ }^{7}$ Allen Lane, "Penguins and Pelicans," Penrose Annual 40 (1938): 40-44, at 41. Emphasis in the original.

${ }^{8}$ Rick Rylance, "Reading with a Mission: The Public Sphere of Penguin Books," Critical Quarterly 47, no. 4 (December 2005): 49-66.

9 Catherine Feely, "Karl Marx, Capital and Radical Book Cultures in Britain, 1881-1945" (PhD diss., University of Manchester, 2011), 171-77. In 1938, probably in reaction to the success of the Left Book Club, Lane claimed that local Pelican Clubs had sprung up around the country, at which readers discussed topics raised by the latest books. These clubs, if they existed, have left no archival trace. See Allen Lane, "Books for the Million... ," Left Review 3, no. 16 (May 1938): 968-70, at 969.

${ }^{10}$ Linda Lloyd Jones, "Fifty Years of Penguin Books," in Fifty Penguin Years, ed. Linda Lloyd Jones and Jeremy Aynsley (Harmondsworth, 1985), 11-104, at 24. 
overwhelmingly come from the middle or artisan classes. They were more likely to be male than female, were typically under forty years of age, and expressed strong loyalty both to Penguin as an enterprise and to book reading as their primary leisure activity. ${ }^{11}$ For those individuals who spent a great deal of time and effort on private selfimprovement, Lane's invocation of a democratic reading public was a source of considerable cultural value.

In this article, I reconsider Penguin Books' embrace of the techniques of mass production, distribution, and retail, and how these were used to market the notion of an engaged public readership. In particular, I explore the crucial work done by the familiar Penguin mascot, the monochrome cartoon of a King penguin that appeared on all of Penguin's book covers, its advertisements, and its in-store promotional material. Despite the cultural ubiquity and iconic status of this bird, it has never received any critical attention either from Penguin's many historians, who tend to dismiss it as a lovable whimsy, or from historians of Britain more generally. ${ }^{12}$ Yet as the initial teaser advertisement made clear, Penguin's affable mascot was always vital to how the books were framed, sold, and culturally positioned. If the penguins were indeed coming, then the mascot's anthropomorphism allowed it to act as a proxy both for the new paperbacks and for members of that enlightened public which they now promised to foster.

By 1937, the decision to deploy a cartoon penguin had become central to the company's mythology. ${ }^{13}$ The most authoritative version of the tale was published fifteen years later by Edward Young, who, as a young man of twenty-one, had been responsible for all of Penguin's book production and publicity:

I remember well the final conference on this, the most difficult point of all.... We had before our minds the successful example of the great Continental series of paperbacks, the Albatross Books, and it was agreed that we too must find a bird or an animal for our mascot. We spent nearly two hours searching the bird and animal kingdoms. ... We were in despair. Then suddenly the secretary's voice piped up from behind the partition (her name, it should be recorded for posterity, was Joan Coles). She said, "What about Penguins?"

It was the obvious answer, a stroke of genius.... I went straight off to the Zoo to spend the rest of the day drawing penguins in every pose from the dignified to the ridiculous, and the following morning produced, at first shot, the absurdly simple cover design which was soon to become such a familiar sight on the bookstalls. ${ }^{14}$

As Young acknowledged, the Albatross books, a continental line of English-language reprints, were an important precedent for Penguin. Since their launch in 1932, their austere front covers, generic color-coding, and sans-serif typography had demonstrated the commercial viability of well-designed, mass-produced

\footnotetext{
${ }^{11}$ Mass-Observation, "A Report on Penguin World," December 1947, FR 2545, 38-58, Mass-Observation Archives (hereafter MOA), University of Sussex. All quotations by permission of the trustees.

12 Phil Baines, Penguin by Design: A Cover Story, 1935-2005 (London, 2005), 13; Kristoffer Bundgaard Almlund, "But Why a Penguin?," Penguin Collector 63 (December 2004): 51-55; Jeremy Lewis, Penguin Special: The Life and Times of Allen Lane (London, 2006), 91; Lloyd Jones, "Fifty Years of Penguin Books," 16; Alistair McCleery, "The Return of the Publisher to Book History: The Case of Allen Lane," Book History 5 (2002): 161-85, at 167.

${ }^{13}$ See Preston Benson, "10,000,000 Books in Two Years from $£ 100$ Capital," Star (London), 7 October 1937; Ian Coster, "He Got the Bird," London Evening Standard, I November 1938.

${ }^{14}$ Edward Young, "The Early Days of Penguins," Book Collector 6 (1953): 210-11, at 210-11.
} 
paperbacks. ${ }^{15}$ Yet their stylized graphic of an albatross in flight was a very different bird from Young's later penguin. Like the phoenix that graced the dust jackets of Chatto and Windus's Phoenix Library (published from 1928 onwards), the albatross was strictly a colophon, an immutable trademark to indicate the volume's manufacturer. The penguin, by contrast, was definitely a mascot. It mutated with ease, proliferating in different guises across the firm's publicity material, to strike a great many poses. ${ }^{16}$

In creating a fully fledged mascot for his new series, Lane built on the semantic achievements of other advertising characters who, since the early 1920s, had presented branded commodities as a force of social progress. Fifteen or so years before Lane launched Penguin Books, anthropomorphic brand mascots had come to dominate British advertising and retail. As production costs fell, wages rose, and more overseas companies sought to enter the British market, mass-produced goods became increasingly ubiquitous within ordinary people's lives. ${ }^{17}$ More and more prepackaged items competed for attention, both on the grocery shelves and on the hoardings, and mascots proved particularly adept at keeping certain products at the forefront of consumers' minds. During the early 1920s, such prewar pioneers as Johnnie Walker, the Quaker (Quaker Oats), and the Kodak Girl were swiftly joined by a vibrant host of others to create what struck many observers as a portentous commercial scene.

Despite their role in framing the social meanings of interwar mass consumption, brand mascots have appeared as only minor characters, if at all, in histories of British advertising and consumerism. ${ }^{18}$ Recently, however, they have gained more attention within marketing studies, whose scholars have been keen to determine the factors that distinguish the successes from the failures. ${ }^{19}$ Here mascots are generally understood as literalizations of "brand personality" a term coined by Burleigh Gardner and

\footnotetext{
${ }^{15}$ McCleery, "The Return of the Publisher to Book History," 165-66. See also Steve Hare, "Creation Myths," The Penguin Collector 76 (2011): 6-11.

16 This was also true of its Pelican sibling, which was used both as a colophon on the company's adulteducation paperbacks and as a mascot in its advertising and promotion.

${ }^{17}$ See W. Hamish Fraser, The Coming of the Mass Market, 1850-1914 (London, 1981); Thomas Richards, The Commodity Culture of Victorian England: Advertising and Spectacle, 1851-1914 (London, 1991); Vernon Ward, "Marketing Convenience Foods between the Wars," in Adding Value: Brands and Marketing in Food and Drink, ed. Geoffrey G. Jones and Nicholas J. Morgan (London, 1994), 259288 , at $260-1$.

${ }^{18}$ See, for instance, John Benson, The Rise of Consumer Society in Britain, 1880-1980 (London, 1994); Robert Fitzgerald, Rowntree and the Marketing Revolution, 1862-1969 (Cambridge, 1995); Matthew Hilton, Consumerism in Twentieth-Century Britain: The Search for a Historical Movement (Oxford, 2003); T. R. Nevett, Advertising in Britain: A History (London, 1982); Stefan Schwarzkopf, "Turning Trademarks into Brands: How Advertising Agencies Practiced and Conceptualised Branding, 18901930," in Trademarks, Brands and Competitiveness, ed. Theresa da Silva and Paul Duguid (London, 2010): 165-93; E. S. Turner, The Shocking History of Advertising, rev. ed. (Harmondsworth, 1965).

${ }^{19}$ See for example Stephen Brown, "Where the Wild Brands Are: Some Thoughts on Anthropomorphic Branding," Marketing Review 10, no. 3 (August 2010): 209-24; Margaret F. Callcott and Wei-Na Lee, "Establishing the Spokes-Character in Academic Inquiry: Historical Review and Framework for Definition," Advances in Consumer Research 22 (1995): 144-51; Sameer Hosany et al., "Theory and Strategies of Anthropomorphic Brand Characters from Peter Rabbit, Mickey Mouse and Ronald McDonald, to Hello Kitty," Journal of Marketing Management 29, nos. 1-2 (2013): 48-68; Barbara J. Phillips, "Defining Trade Characters and Their Role in American Popular Culture," Journal of Popular Culture 29, no. 4 (Spring 1996): 143-58; Barbara J. Phillips, "Spokes-Characters: Assurance, Insurance and Advice for
} 
Sidney Levy in 1955 to describe those associative qualities that consumers use to differentiate between similar mass-produced items. ${ }^{20}$ By embodying the imagined qualities of their brand, advertising characters are seen to promote a deeper and more emotive relationship between the consumer and their product, in which feelings of trust, aspiration, or nostalgia outweigh rational calculations of worth. Yet while many British brand mascots of the 1920s can be made to fit this model, "brand personality" is neither necessary nor sufficient to explain their historical significance. The term especially fails to capture their cultural impact between the wars as a new type of media icon. Appearing nationwide on posters and packaging and in the pages of the tabloid press, advertising characters resembled a heraldic chorus, apparently proclaiming a dawning age of material democracy and empowerment. Their friendly address invited individuals to imagine themselves within a modern consuming public rendered equitable by its affiliation to the same famous brands and exercising a collective sovereignty every time it visited the shops.

In Sounding Brass, Ethel Mannin's 1926 novel about the rise and fall of an advertising mogul, her protagonist wanders the streets of a newly postwar London to find a restless, vital, chaotic city still "in the process of gestation." "The air was thick with slogans concerning making the world safe for democracy; making the land fit for heroes; old orders changing and giving place to new," he observes, sensing the untapped opportunities that will soon generate his fortune. ${ }^{21}$ The exact terms of this link between democratic citizenship and advertised branding were hugely debated within interwar Britain. Socialist thinkers, cultural critics, and advertising professionals all issued calls to either welcome mass consumption as a social benefit or resist it as an engine of cultural decline. ${ }^{22}$ Yet ordinary consumers understood the transformations brought about by branded consumption less through these competing discourses than through their everyday encounters with advertisements and products. By the end of the nineteenth century, advertisers had already begun to frame mass-produced commodities as agents of social empowerment, but this trend became notably more intense in the early 1920s. ${ }^{23}$ Buoyed by what was, for many, a rise in the standard of living, working-class gains at the parliamentary ballot box seemed to be echoed by comparable advances at the grocer's. Matthew Hilton, for instance, has noted how interwar advertisements for branded cigarettes frequently asked their viewers to picture themselves within an empowered crowd

Marketers," in Brand Mascots, and Other Marketing Animals, ed. Stephen Brown and Sharon PonsonbyMcCabe (London, 2014), 165-74.

${ }^{20}$ Burleigh B. Gardner and Sidney J. Levy, "The Product and the Brand," Harvard Business Review (March-April 1955): 33-39.

${ }^{21}$ Ethel Mannin, Sounding Brass (London, 1937), 97.

${ }^{22}$ Hilton, Consumerism in Twentieth-Century Britain, 79-136; D. L. LeMahieu, A Culture for Democracy: Mass Communication and the Cultivated Mind in Britain between the Wars (Oxford, 1998), 16065; Nevett, Advertising in Britain, 153-56, 160-68; Nicole Robertson, The Co-operative Movement and Communities in Britain, 1914-1960: Minding Their Own Business (Farnham, 2010), 45-72; Stefan Schwarzkopf, "Respectable Persuaders: The Advertising Industry and British Society, 1900-1939" (PhD diss., Birkbeck College, 2008). See also F. R. Leavis and Denys Thompson, Culture and Environment: The Training of Critical Awareness (London, 1933); "Over 300 Advertising Men Sign the Convention Creed," Advertiser's Weekly, 14 November 1924, 267-69.

${ }^{23}$ Lori Anne Loeb, Consuming Angels: Advertising and Victorian Women (Oxford, 1994). 
of equitable smokers. ${ }^{24}$ This dynamic went further than just tobacco, however, and was endemic to the basic structure of branded mass production. Due to their economies of scale and geographical distribution, prepackaged items could inherently gesture toward greater material parity and wider social inclusion. This address was made most acutely by anthropomorphic advertising characters, who proffered a form of democratic participation that was apparently indifferent to social class and exercised through the household shop.

Such was the mascot's cultural power that when Lane planned his paperbacks in the mid-1930s, the need to create his own was taken as a given. Choosing a brand character, and specifically a penguin, allowed him to appropriate the utopian dynamics of mass consumption and mold it to fit his own progressive cultural project. Penguin's mascot became one of mid-century Britain's most notable harbingers of social democracy. Featured on book covers and on in-store material, the cartoon bird provided a vital mechanism through which individual browsers learned to align themselves with its lucratively imagined public sphere.

\section{"THAT'S US": BRAND MASCOTS AND CONSUMER DEMOCRACY}

From the perspective of almost a century later, the sudden proliferation of brand mascots in the decade after the Great War is particularly striking. At the end of 1922, the leading trade journal, the Advertiser's Weekly, enthused about the "greatly increased employment by advertisers of advertising personalities" during the previous year, while the writer Oliver Minns noted their "increasing ubiquity" and their obvious popularity with the public. ${ }^{25}$ By 1924, Carlton Studios was promoting its roster of commercial artists through the "first class salesmen" they had recently produced, including Pessy an' Oppy (Bondman Cigarettes), the Marmite Girl, and "Grandpa" Kruschen. ${ }^{26}$ By the middle of the decade, however, such enthusiasm was tempered by the first voices of dissent. H. Wentworth James, for instance, decried "the insane use of advertising figures ... depicting insane characters making silly remarks in impossible situations, and the worst of it is that the deplorable mannikins are all tending to resemble one another more and more." ${ }^{27}$ Copywriting manuals soon cautioned their students not to create mascots as a lazy default option, since many manufacturers had already been saddled with costly and conspicuous failures. "A great many of them should never have come into the world at all," warned R. Bigelow Lockwood in 1929, "and, for the sake of good advertising, the quicker they pass out of it the better." 28

\footnotetext{
${ }^{24}$ Matthew Hilton, "Advertising the Modernist Aesthetic of the Marketplace? The Cultural Relationship between the Tobacco Manufacturer and the 'Mass' of Consumers in Britain, 1870-1940," in Meanings of Modernity: Britain from the Late-Victorian Era to World War II, ed. Martin Daunton and Bernhard Rieger (Oxford, 2001), 45-69.

${ }^{25}$ C. Thompson Walker, "Press Advertising in 1922," Advertiser's Weekly, 19 January 1923, 84; Oliver A. Minns, What You Should Know about Advertising (London, 1922), 103.

26 "Carlton Work Has but One Duty-It Must Sell Something" (advertisement), Advertiser's Weekly, 15 August 1924, 464-65; "Personality in Advertising" (advertisement), Advertiser's Weekly, 5 September $1924,569$.

${ }^{27}$ H. Wentworth James, “Pretty' Advertising v. Mannikins,” Advertiser's Weekly, 6 April 1923, 10.

${ }^{28}$ R. Bigelow Lockwood, Industrial Advertising Copy (London, 1929), 199.
} 
This sudden flurry of postwar mascots came in many different forms. At one end of the scale were the simple grotesques who appeared in a succession of silent poses, for example, Sir Kreemy Knut (Sharp's Toffee) and the Fry's Girl. Of greater complexity were the speaking characters who imparted with confidence the benefits of their particular product, such as Uncle Cheeriboy (Page Woodcock's Pills) and McNab (Spey Royal Whisky). Soon, brand mascots were even starring in their own dedicated comic strips (for example, the Panshine Pair) or in short narrative movies at the cinema (for example, Plain Mr. York of York, Yorks., for Rowntree's Chocolate). Despite these varying grades of sophistication, however, advertising writers were quick to discern a common underlying structure. In one of the first theorizations of the phenomenon, J. Walter Thompson positioned brand mascots halfway between the static, inflexible trademark (which always remained the same for legal reasons) and the ephemeral advertisement (whose need to attract attention entailed a constant pursuit of novelty). Such advertising characters revolved around a few memorable or distinctive traits, which were then replayed within a succession of different scenarios. They provided, he wrote, "an identifying landmark to the voyager in these weltering seas of change." 29

For advertising experts, this combination of repetition and novelty defined the mascot's essence. As Thomas Russell, inventor of the Brown \& Polson CheckApron Girl, explained, "The way to use a mascot efficiently is to show the figure in one posture long enough to make it familiar; after that, get a new effect by showing it in all kinds of attitudes, doing all kinds of things." ${ }^{30}$ Each iteration would thus retain the viewer's attention long after its initial capture. Established mascots produced "a cumulative effect" that kept their brand on the tip of customers' tongues when they ordered that type of product in the shops. ${ }^{31}$

Copywriter Constance Miller also advised her students to keep their mascots moving:

The copy-writer should not permit the trade-figure to be inactive. It can always be clothed in the same garments, but it should be made to perform in some way. In the Monserrat advertising, Monty [an anthropomorphic lime] not only talks, but he acts. He swings in a hammock, looking the very essence of coolness and calm. He dares a thermometer and the liquefying sun, by pointing to them. He pours out a drink of Monserrat Lime Juice for himself as he invites others to partake of the cooling beverage. ${ }^{32}$

This focus on serial action reveals the strong parallel between the brand mascot and the film star as two confluent mass-media figures that gained prominence in Britain at around the same time. By the early 1920s, Hollywood actors effectively functioned as advertising characters for their studio, likewise reduced to a few distinctive traits and presented within a succession of scenarios that differed only mildly. ${ }^{33}$

${ }^{29}$ J. Walter Thompson, Things to Know about Trademarks (New York, 1911), 45.

30 Thomas Russell, Commercial Advertising: Six Lectures at the London School of Economics and Political Science (University of London), Lent Term 1919 (London, 1919), 164.

${ }^{31}$ Ibid., 138.

32 Constance E. Miller, How to Write Advertisements (London, 1924), 209.

${ }^{33}$ Richard deCordova, Picture Personalities: The Emergence of the Star System in America (Urbana, 1990). 
Miller even ascribed to brand mascots their own cinematic genres: the "comical" Monty, the "serious" Quaker, the happy and "care-free" Kodak Girl, and so on. ${ }^{34}$

Like human film stars, the most popular brand mascots of the early 1920s developed a managed off-screen "reality." At each of the three major Advertising Exhibitions held in London in 1920, 1927, and 1933, members of the public could meet famous characters in person, an opportunity always met with great enthusiasm. ${ }^{35}$ At the 1927 show at Olympia, for instance, a Palace of Beauty presented the Ovaltine Dairy Maid, the "original" Lyons's Nippy, the Kodak Girl, and other well-known poster starlets in a series of tableaux vivants. ${ }^{36}$ In a striking demonstration of what Michael Saler terms the "ironic imagination," patrons took an active enjoyment in imagining the life-worlds of these fictional characters, even as they knew that they did not really exist. ${ }^{37}$ Such investments were not always so self-aware, however. In 1923, for instance, Wix \& Sons, Ltd. revealed their receipt of a great many letters addressed to "Dear Mr. Jenkyn," the fictitious butler who extolled the virtues of their Kensitas Cigarettes. "When a man ... addresses himself to the symbol of the advertising it reflects belief in the reality of that symbol," commented a clearly impressed Advertiser's Weekly. 38

Brand mascots and movie stars were both devices by which ordinary Britons learned to negotiate experiences of social change in the 1920s and '30s. As Richard Dyer notes, the popular appeal of Hollywood stars lay in their paradoxical conflation of the exceptional and the ordinary. ${ }^{39}$ Both off-screen and on, their reified existence was far removed from the lives of their average British fans, but they still appeared to face similar dilemmas concerning love, family, and personal fulfillment. British cinemagoers came to both idealize and identify with particular stars and found in their actions a pragmatic set of tactics that could be deployed to address their own situations. ${ }^{40}$ Advertising mascots provided a similar resource. Although lacking any real human referent-in this sense, their life-worlds were even more impervious than Hollywood-the fictional scenarios in which they appeared typically centered on the solution to a common household problem. Brand characters often posed as friendly experts, dispensing key advice of which the reader was

${ }^{34}$ Miller, How to Write Advertisements, 210.

35 James Taylor, “A Fascinating Show for John Citizen and His Wife': Advertising Exhibitions in Early Twentieth-Century London," Journal of Social History 51, no. 4 (July 2018): 899-927.

36 "Along Shop Window Street, and the Features that 'Fetched' the Public," Advertiser's Weekly, 22 July $1927,274-75$.

${ }^{37}$ Michael Saler, “Clap If You Believe in Sherlock Holmes': Mass Culture and the Re-Enchantment of Modernity, c.1890-c.1940," Historical Journal 46, no. 3 (September 2003): 599-622.

38 "The Value of the Advertising Character," Advertiser's Weekly, 10 July 1923, 145-6, at 145.

${ }^{39}$ Richard Dyer, Stars, new ed. (London, 1998), 43-44.

${ }^{40}$ See Carol Dyhouse, Glamour: Women, History, Feminism (London, 2010), 35-98; David Fowler, The First Teenagers: The Lifestyle of Young Wage-Earners in Interwar Britain (London, 1996); Nicholas Hiley, "Let's Go to the Pictures': The British Cinema Audience in the 1920s and 1930s," Journal of Popular British Cinema 2 (1999): 40-45; Annette Kuhn, "Memories of Cinema-Going in the 1930s," Journal of Popular British Cinema 2 (1999): 100-20; Jackie Stacey, Star Gazing: Hollywood Cinema and Female Spectatorship (London, 1994); Melanie Tebbutt, Being Boys: Youth, Leisure and Identity in the Inter-War Years (Manchester, 2012). See also the testimonies of film fans collected in J. P. Mayer's Sociology of Film: Studies and Documents (London, 1946). 
assumed to be in need, while their appeal as objects of playful identification was made unassailable by their otherworldly nature.

Perhaps unsurprisingly, many of the decade's most successful mascots were perfect yet practical incarnations of the housewife. The Little Red Ring Lady, for instance, retained an improbably immaculate appearance as her succession of dishes (all made with Red Ring Self-Raising Flour) flowed effortlessly from the oven. The absurd impracticality of her fairy-like full skirt was made tenable by the fact that she was obviously a cartoon. Likewise, Vimmy, the mascot imp of Vim Cleanser \& Polisher, delivered sparkling silverware without the slightest hint of effort or toil. An effective externalization of the housewife's own labor, he deigned to sell it back to her as a magical prosthesis. Even those advertising characters depicted outside of a domestic setting-like Monty the lime, relaxing in his hammock-proffered a state of blissful contentment that using that product now promised to instill. That none of these mascots was at all realistic was their own indemnifying alibi.

This structural invitation to identify with a mascot was sometimes made explicit. In October 1919, for instance, the confectioner Rowntree and its advertising agency, S. H. Benson, Ltd., launched a new pair of characters called the Cocoa Nibs. ${ }^{41}$ In their simple debut poster, the ruddy faces of a boy and girl beamed out from a plain black background, each wrapped in a long colored scarf that would soon become their hallmark. Framed between the branded product above (Rowntree's Cocoa) and their introductory caption below ("THE COCOA NIBS"), the pair held out cups of steaming cocoa that were both gifts to the viewer and the source of their own glee. The poster's message was relatively straightforward: drinking Rowntree's Cocoa would invigorate your children, or else make you more invigorated and youthful, on a chilly winter's day. Yet more revealing was the second poster that replaced it on the hoardings four months later (figure 2). Now the original advertisement had become a poster-within-a-poster, to which the "real" Nibs gestured from a position on the pavement. Not only did this draw attention to the Cocoa Nibs' status as mass-media celebrities, but it gave the viewer an explicit instruction on how to relate to their image. The updated caption ("That's us") both described the narrative of self-recognition within the poster's narrative and prescribed an act of identification to human viewers on the street, who now found themselves to be gazing up at two mascot surrogates on the wall.

At least some of this poster's viewers took its central message to heart. During the Nibs' first year of operation, Rowntree received almost 450 unsolicited requests for Cocoa Nibs fancy-dress costumes. The firm's staff responded by cutting out sets of paper scarves, face-masks, and cocoa cups from surplus copies of the original poster-an extraordinary literalization of the second poster's message. ${ }^{42}$ Indeed, brand mascots were popular as costume choices all through the fancy-dress craze of the 1920s. In January 1923, for instance, a ball at London's Queen's Gardens Court Hotel saw guests arrive as the Fry's Girl, Vimmy, the Kodak Girl, and others. First prize was awarded to Cardinal Wolsey, the recently appropriated mascot of the eponymous branded knitwear range. ${ }^{43}$ Advertisers and their agencies

${ }^{41}$ On the birth of the Cocoa Nibs, see Fitzgerald, Rowntree and the Marketing Revolution, 139-41.

42 "Rowntree Annual Advertising Report (1919-20)," 79, HAT 21/286, David Lamb Rowntree Collection, History of Advertising Trust.

43 "Ad. News in Brief," Advertiser's Weekly, 19 January 1923, 76. 


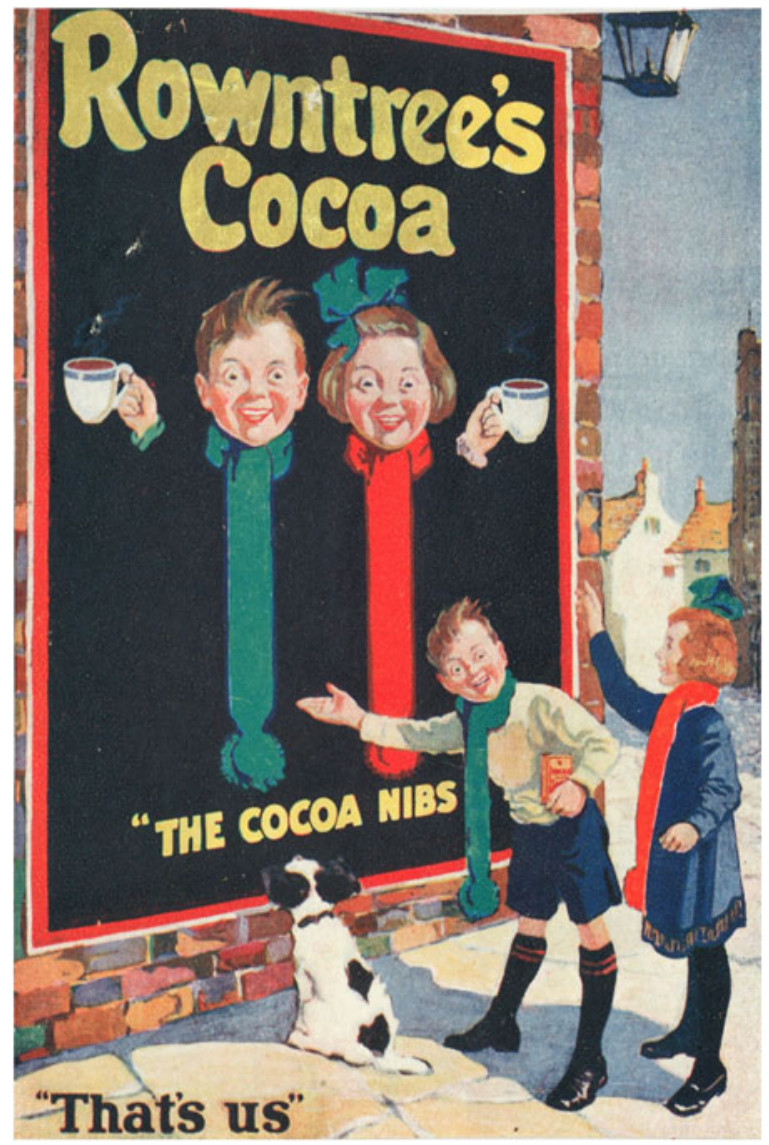

Figure 2-Poster advertisement for Rowntree's Cocoa, February 1920. David Lamb Rowntree Collection, History of Advertising Trust. By permission of Nestlé UK.

soon gauged the success (or otherwise) of their mascots by the extent to which the public dressed up. George Royds, who invented the Beefex Fighting Boy, for instance, bragged of the hundreds of children who had picked his mascot "and literally won dozens of 'firsts." 44 We lack the archival evidence, but part of the pleasure in wearing such costumes surely came from their license to embody, if only for an evening, the exaggerated traits of one's favorite commercial role model.

The pleasure of fancy dress, of course, also lies in the mutual recognition of each other's chosen disguise. The prevalence of advertising characters at such events in the 1920s thus reveals how swiftly brand mascots had entered the popular vernacular. To follow Michael Warner's formulation, these new mass-media advertising stars were creating their own publics. The implicit recognition that a certain mascot was also

${ }^{44}$ George S. Royds, Brasstacks: The Case for Sanity in Advertising (London, 1933), 65. Mr. F. Tucker of Fry's \& Sons, Ltd. also gauged the success of his firm's "Fry's Girl” in this way; see Advertiser's Weekly, 21 August 1925, 312. 
being enjoyed by millions of unknown strangers bound the viewer into an imagined audience that was only connected via the mascot itself. ${ }^{45}$ Fancy-dress dances were a palpable response to this cultural experience. Bonded by their shared investment in these peculiar new characters, the gathered guests served as a festive synecdoche for the larger unknown public produced by their brands. It is hard not to see in these costume choices a certain utopian impulse, an eagerness to embrace the markers of an apparent social parity rooted in affiliation to the same mass-produced commodities.

These affective dynamics were clearly in evidence in 1920, when the organizers of the International Advertising Exhibition, about to open at London's White City, staged a Pageant of Advertising to drum up interest in the fair. On a rainy Saturday afternoon in November, several hundred thousand spectators watched a mile-long cavalcade of floats zigzag its way through the streets of the West End, from Marble Arch to Kingsway. ${ }^{46}$ This pageant sought to communicate the social benefits of professional advertising and was billed to star "all or most of those goods the name and use of which is known in every home." 47 Yet for people lining the route, the real attraction was its extensive cast of brand mascots, impersonated for the day by human actors. The Daily Mail (whose reliance on branded advertising should not be forgotten) recorded an informal atmosphere of great jollity: "In the mile of mirth were figures which have been intimately familiar to millions in newspaper display advertisements, posters, and other advertising media-figures suddenly come to life, throwing merry jests-and samples-to the crowds, who joked back as if with old friends." 48 Even advertising professionals were surprised by the apparently spontaneous camaraderie. As R. H. Currington wrote in the Advertiser's Weekly, "I doubt whether anyone seeing [the procession] could deny the value of the advertising figure. The Kodak Girl, little Vim, the 'Bubbles' boy, the lifebuoy men-all the figures obtained immediate recognition at the hands of the spectators. ... The public would certainly appear to entertain an affection for these advertising figures-an achievement that gives one something to think about." 49

In a recent discussion of this Pageant of Advertising, James Taylor notes how journalists' reports frequently stressed the social diversity of the crowd, especially in terms of age and class. "Familiarity with [these characters]," he writes, "was something shared by everyone, binding the nation together." ${ }^{\circ 0}$ Yet as a public spectacle, the pageant's real force came from its assembly of so many characters in the same place at one time. So gathered, the mascots drew attention to their own ubiquity, as well as to that of the household products whose fame they mutually reinforced. The parade's sheer scale proclaimed a new era of universal material citizenship, as the jolly cavalcade reflected back to the crowd an image of its happier, more sated future self. By highlighting the jokey interactions and the ready distribution of samples, the press

${ }^{45}$ Michael Warner, Publics and Counterpublics (New York, 2002), 65-124.

46 "The Pageant of Publicity," Advertiser's Weekly, 30 November 1920, 328.

${ }^{47}$ Barrington Hooper, "The Great Pageant of Publicity: When and Where to See the Parade of Big Figures in British Advertising," Advertiser's Weekly, 26 November 1920, 273.

48 "Mile of Mirth," Daily Mail (London), 29 November 1920, 10.

49 R. H. Currington, “The Practical Side,” Advertiser's Weekly, 3 December 1920, 361.

50 Taylor, "A Fascinating Show," 906. 


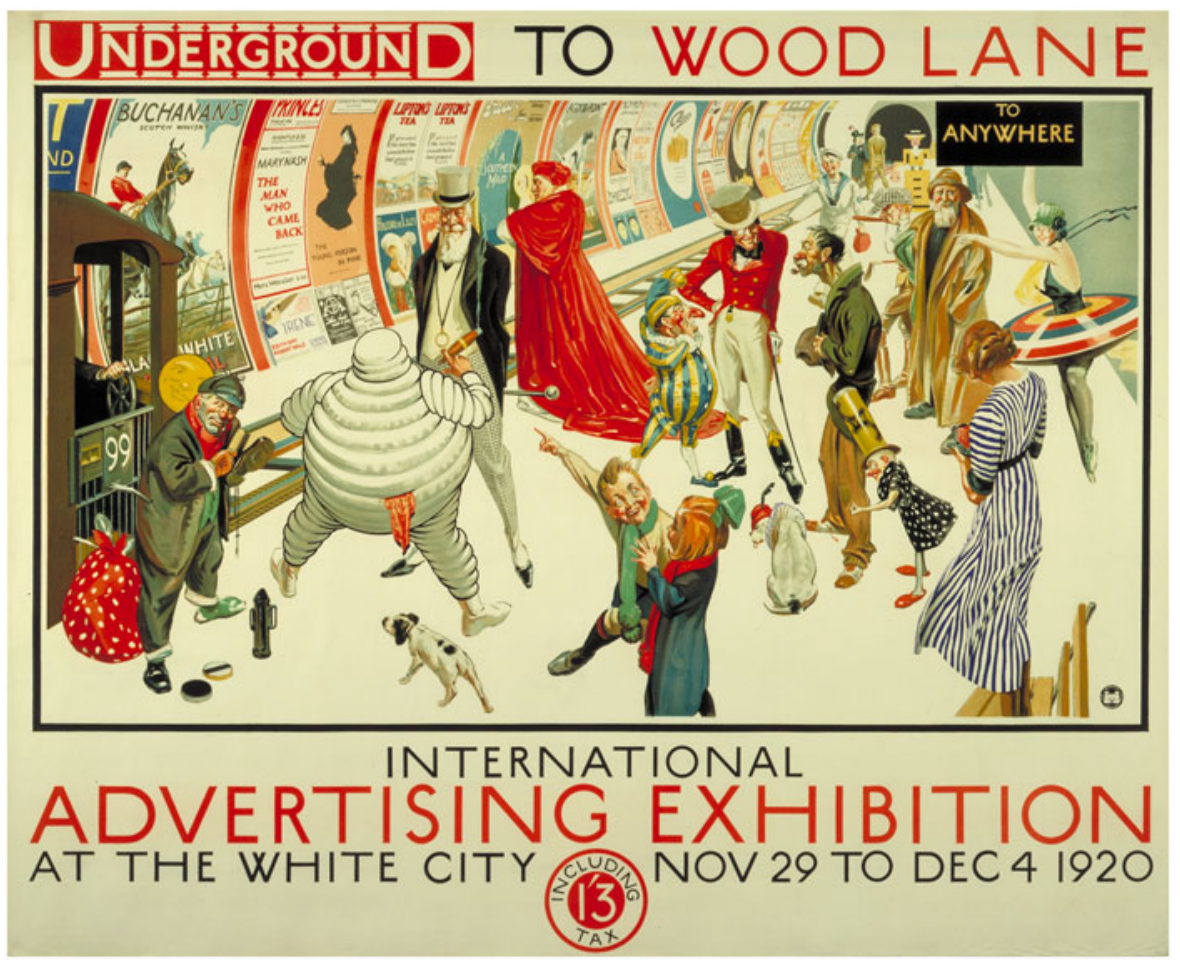

Figure 3-Underground poster by H. C. Herrick for the International Advertising Exhibition, 1920. (C) TfL from the London Transport Museum collection.

rendered the boundary between the mascots and the audience porous, as the latter became progressively absorbed into the former's colorful utopia.

When H. C. Herrick designed a poster to publicize the same exhibition on the walls of the London Underground, he likewise presented a crowd of mascots waiting on the platform for their Tube train to the show (figure 3). With its pictorial echoes of Victorian railway-terminus panoramas (such as William Powell Frith's "The Railway Station" of 1862), this strange miscellany was framed as a holistic social scene by the Kodak Girl's viewfinder in the bottom-right-hand corner. Human viewers awaiting their own incoming train presumably passed the time by identifying all the mascots on the poster, at which moments the parallels must have been obvious. Here, then, was another invitation to find one's place among a merry band of advertising characters and effectively join that spirited new society that branded mass consumption now promised to deliver.

Perhaps the timeliest aspect of Herrick's poster was its intimations about social class. His chosen characters conspicuously ranged from the aristocratic (Johnnie Walker and Wolsey) through the comfortably middle-class (the Kodak girl) to the impoverished down-and-out (Dirty Dick, the Pears Soap tramp). Yet so assembled on the platform, their striking diversity only underscored the apparent social reach of their branded products. In this promised land of mass consumption, whisky 
would no longer remain the privilege of the wealthy, and even the most destitute would afford a bar of soap. The poster thus expressed the same social optimism as its contemporary fancy-dress balls (which these characters might equally have been catching a train to attend). In a society dominated by branded products, the signifiers of social class promised to function less as markers of harsh inequality and more as matters of personal style.

As the 1920s wore on, advertisers became adept at interpellating readers into their brand's projected public. In September 1923, for instance, Rowntree and Benson's announced a quest to find "clever and attractive names" for the two Cocoa Nibs children and their dog. Entrants had to submit three names that were catchy, easy to remember, and consisting solely of the letters within "ROWNTREE'S COCOA-FINEST FOR FLAVOUR." 51 To win, contestants had to position themselves in the role of Rowntree's advertising agents and contemplate the abstract public among whom their names would resonate. In the end, Mrs. Dawbarn of Hove and Miss Millward of Bedford beat 400,000 others with the same suggestions: "Colin," "Carrie," and "Cute" the dog. For this alliterative trio, they shared an enormous $£ 500$ cash prize. $^{52}$ Six months later, Rowntree's rival, J. S. Fry \& Sons, launched a similar contest to name their own recent mascot, the Fry's Girl, but now the rhetoric of collective empowerment was even more acute. Readers were asked to rank a list of ten preselected girls' names in order of popularity - to anticipate, in effect, the democratic will. Some 628,000 people sent in their coupons; fifteen predicted the aggregate result and won a prize of $£ 100$ each. ${ }^{53}$ Significantly, the newly christened "Phyllis" never took up her proper name in public. Like the Cocoa Nibs before her, she retained her original, more lucrative brand moniker for the rest of her rather brief life.

Stunts like these effectively dramatized what advertising professionals had already identified as the democratic nature of branded products. In what were now cast as the bad old days, local grocers had measured out unbranded wholesale goods in response to each customer's needs, a process that left shoppers endemically open to adulterated goods and dishonest claims. ${ }^{54}$ Yet mass production transformed this situation by lessening the mediation of the shopkeeper and forging a direct channel of communication between the customer and the maker. As Gilbert Russell explained in 1926: "The moment wares are distinguished by a brand ('branded,' for the sake of brevity) the public has a means of knowing them for good or ill. If they are of good quality the brand is easy to remember. And if they are of poor quality the brand is still easy to remember-and easy to avoid." 55 Since branded products were usually

51 “ $£ 2000$ for Naming the Famous Rowntree’s Cocoa Nibs" (advertisement), Daily Mirror (London), 13 September 1923.

52 "Results: Rowntree's Cocoa" (advertisement), Daily Mirror (London), 5 December 1923, 13.

53 "Fry's Girl Name Competition," Advertiser's Weekly, 11 April 1924, 65.

${ }^{54}$ See Rachel Bowlby, Carried Away: The Invention of Modern Shopping (London, 2000); Mica Nava, "Modernity Tamed? Women Shoppers and the Rationalization of Consumption in the Interwar Period," in All the World and Her Husband: Women in Twentieth-Century Consumer Culture, ed. Maggie Andrews and Mary M. Talbot (London, 2000), 26-64; Janice Winship, "Culture of Restraint: The British Chain Store, 1920-1939," in Commercial Cultures: Economies, Practices, Spaces, ed. Peter Jackson et al. (Oxford, 2000), 15-34.

55 Gilbert Russell, Nuntius: Advertising and Its Future (London, 1926), 9; emphasis in original. See also Charles Higham, Advertising: Its Use and Abuse (London, 1925), 23. 
advertised and sold on a national scale, he argued, their manufacturer's survival depended on retaining the support of that consuming public that they served to create. If a certain named product failed to meet its advertised claims, then housewives would know not to buy it a second time. Only brands of consistent quality would earn themselves a place within the nation's lexicon and larder. By this same logic, any brand's longevity-either in the shops or on the hoardings-could already be taken as empirical evidence of its proven worth. After all, thousands of shoppers must be regularly buying it, finding it satisfactory, and buying it again. Thus, Russell claimed, a branded article put the manufacturer "at the public's mercy." 56 Grocery shopping was reconfigured as an act of quotidian democracy. Each ordinary purchase became a tiny vote in an ongoing national plebiscite.

This discursive structure was most eloquently expressed during the general election of November 1922. ${ }^{57}$ The day after the vote, an advertisement for Rowntree's Elect Cocoa appeared in the Daily Mirror and other newspapers in which the nowfamiliar Cocoa Nibs waved from their balcony to an assembled crowd below (figure 4). Connecting the two drawings was the text of an acceptance speech, issued by Rowntree but ventriloquized through its mascots:

\section{Ladies and Gentlemen,}

We wish to thank you for electing Elect Cocoa. Why have you chosen it? (A voice from the crowd: "Because we like it.") Yes, because of its Flavour. That is one reason. But what keeps Rowntree's Cocoa at the top of the poll is the fact that we have always made it "the standard of excellence." PURITY, QUALITY, ECONOMY - these, ladies and gentlemen, are our watchwords which give us our big majorities. (Cheers. The crowd breaks $u p$, singing: "For it's a jolly good Cocoa.") ${ }^{58}$

Here the consumer found vocal empowerment, but only as a member of an imagined mass market. What was in reality a dispersed aggregate of individuals, united only by their purchase of Elect Cocoa-and also, in this case, by their reading of the Daily Mirror - could be cast as an enfranchised public, but only via the figure of a pair of fictional mascots. The advertisement's demos displayed the same conspicuous diversity of class and age as in earlier press reports of the Pageant of Advertising. Nationally branded products again appeared as both great social levelers and agents of cross-class integration, transposing the rhetoric of parliamentary democracy onto the ordinary household shop.

By the end of the 1920s, the enthusiasm surrounding this initial proliferation of brand mascots appears to have subsided. While a steady stream of advertising characters continued to be born, those with the greatest cultural impact now displayed increased levels of complexity and forethought. In 1926, for instance, Benson's

\footnotetext{
${ }^{56}$ Gilbert Russell, Advertisement Writing (London, 1927), 54. For a similar claim, see Thomas Russell, "The Basic Principles of Successful Advertising," in What I Know about Advertising, ed. T. B. Lawrence (London, 1921), 3-29. 36.

${ }^{57}$ Penguin, "Exploiting Public Interest in the Election," Advertiser's Weekly, 24 November 1922, 634

58 "Election Result, Rowntree's Top of the Poll" (advertisement), Daily Mirror (London), 16 November 1922, 12. Emphasis in original.
} 


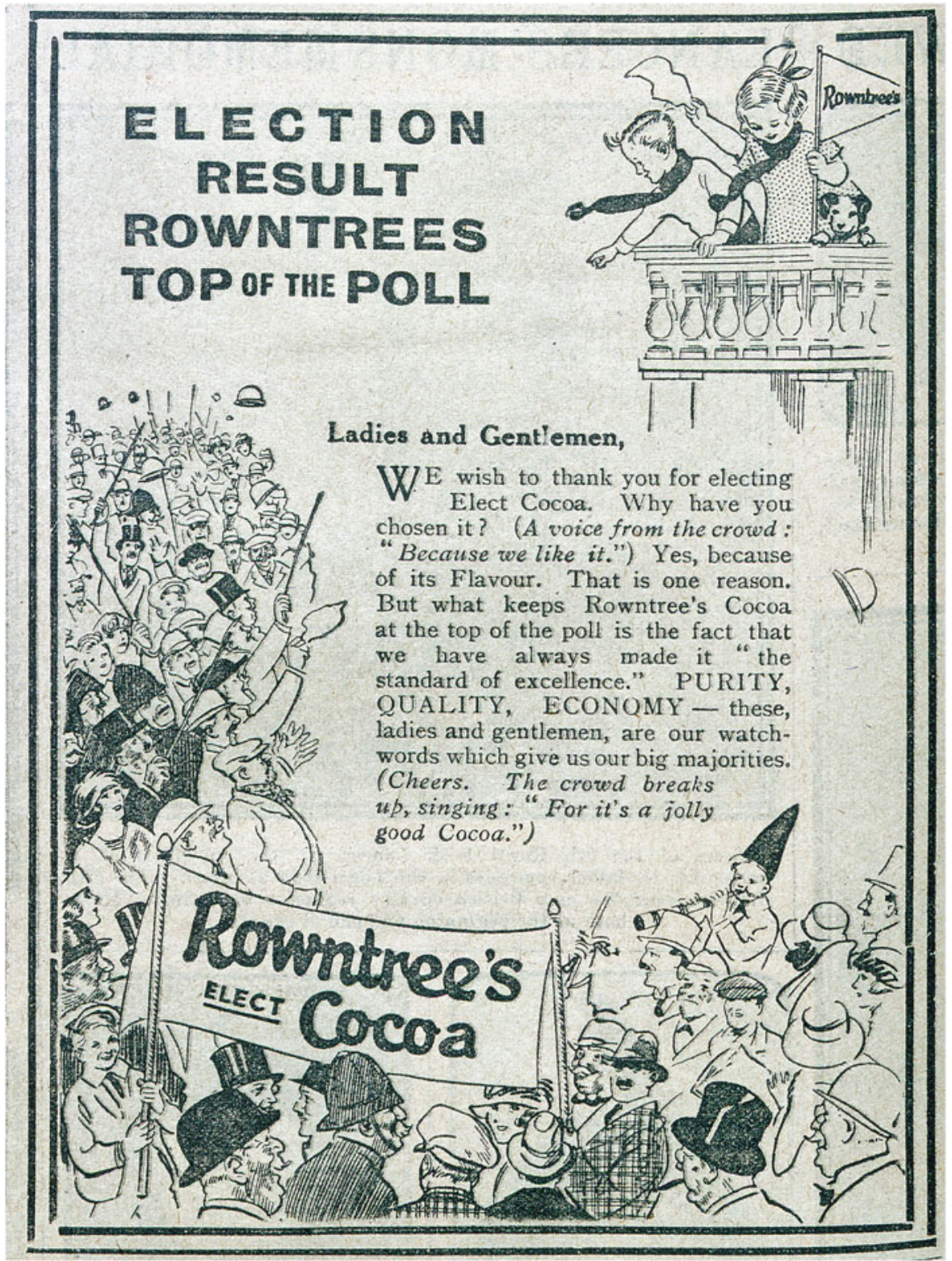

Figure 4-Newspaper advertisement for Rowntree's Elect Cocoa, Daily Mirror (16 November, 1922), 12. By permission of Nestlé UK.

launched the Mustard Club for Colmans Mustard, eschewing the usual mascot star for a companionate cluster of six. Such pun-laden characters as the Baron de Beef, Signor Spaghetti, and Miss Di Gester brought the social diversity of Herrick's poster within the purview of a single brand, while adding a note of cosmopolitan 
modernity. As the preliminary poster slogans made clear ("Has FATHER joined the Mustard Club?"; "Have you joined the Mustard Club?"), to purchase a tin of Colmans Mustard was already to be subsumed into this merry band. The Mustard Club was an immediate cultural sensation, and sales of Colmans Mustard went up by 50 percent within the first three months. ${ }^{59}$

More significant for the present essay was a second campaign by Benson's for the brewing company Guinness in 1935. A series of advertising posters featured a portly, jovial zookeeper who repeatedly exclaimed, "My Goodness, my Guinness!" as he lost his stout to a succession of audacious charges. While the unnamed keeper-allegedly a self-portrait of the poster artist, John Gilroy-provided the mascot's traditional continuity, viewers were led to identify with the litany of stout-consuming animals (a seal lion, a tortoise, an ostrich, and so on). ${ }^{60}$ The creatures served as a thinly veiled synecdoche for the brand's mass public, whose social diversity was both imagined and celebrated via a friendly, unthreatening zoomorphism. Species variation thus became a metaphor for human differences of age, class, and gender. Firmly contained within the institution of the zoo and never mounting a proper challenge to the paternalism of their keeper, these animals appeared as cheeky pranksters rather than as serious miscreants. For all its heterogeneity, then, the Guinness menagerie lacked the unruly energy of the untamed mascots that had burst onto the scene in the early 1920s. By the middle of the 1930s, advertising characters had become more docile and were ready to be assimilated into more ordered social visions of mass consumption.

\section{"PILES OF PENGUINS": UTOPIAN AESTHETICS AND MASS DISPLAY}

Just as the Guinness animals were appearing on the hoardings, Edward Young's own bird arrived in the shops. Penguin's adoption of a cartoon mascot clearly signaled the firm's embrace of branded mass production, not only as an economic system, but also as a social force and a cultural proposition. The Penguin mascot reworked the democratic notions of material citizenship that had become attached to advertising characters in the 1920s and revised them to articulate a leftist vision of a mass-market public sphere. The bird quickly registered as a herald of social-democratic enlightenment, especially when encountered in its natural habitats of the "variety" multiple store and the bookstall.

Since the Great War, fiction reading had become an increasingly popular pastime among the working and lower-middle classes, particularly those in the south of England and the Midlands, who now often enjoyed shorter working hours, lessexhausting labor, and generally improved living conditions. ${ }^{61}$ Most middle-class readers relied on the chains of subscription libraries run by firms such as Boots

\footnotetext{
${ }^{59}$ Leslie Lewis, "How Mustard Found Its Way into Everybody's Mouth," Advertiser's Weekly, 10 December 1926, 397; “Ad. News in Brief," Advertiser's Weekly, 31 December 1926, 542.

${ }^{60}$ Jim Davies, The Book of Guinness Advertising (London, 1998), 36.

${ }^{61}$ Hilliard, To Exercise Our Talents; Robert James, Popular Culture and Working-Class Taste in Britain, 1930-9: A Round of Cheap Diversions (Manchester, 2010), 27-28.; Joseph McAleer, Popular Reading and Publishing in Britain, 1914-1950 (Oxford, 1992); Jonathan Rose, The Intellectual Life of the British Working Classes (New Haven, 2010).
} 
and W. H. Smith, from which volumes could be borrowed on receipt of an annual fee and a sizable deposit. ${ }^{62}$ In contrast, working-class readers obtained their fiction mainly from cheap magazines such as Red Star Weekly and Lucky Star, or from the "twopenny libraries" that sprung up rapidly in urban areas in the first half of the 1930s. ${ }^{63}$ The latter were often administered by neighborhood newsagents, who loaned out books for only two pence a time and crucially required no deposit or subscription.

Encouraged by the success of these ventures, Lane set out to turn these legions of book-borrowers into the regular buyers of books. In 1935, a typical first-print novel cost $7 \mathrm{~s}$. 6d., while subsequent cheaper reprint editions, still produced in hardback, were priced at around $2 \mathrm{~s}$. $6 \mathrm{~d}$. By harnessing the techniques of mass production, distribution, and retail, Penguin was able to issue reprints in paperback at a price of only sixpence, although their commercial success lay in more than just their economy. ${ }^{64}$ Lane also sought to increase the accessibility of quality fiction to working-class readers by altering the geographies of bookselling. Many ordinary readers, he believed, felt too intimated to enter conventional bookshops. Perceiving their own lack of literary capital, they feared provoking a humiliating encounter with an educated, gatekeeping bookseller: "They feel at home in a tuppenny library or at Woolworths, where they get the same amount of attention if they spend 5s. or if they go out with nothing at all; but the idea of braving an empty bookshop with two or three assistants lying in wait behind the shelves is too much for them."65 Lane thus oriented his paperbacks toward F. W. Woolworth \& Co. Ltd. and other "variety" chain stores, whose customers were able to browse the merchandise directly. ${ }^{66}$ Yet since Woolworth's top price was sixpence per item, this economic model required each Penguin title to sell many tens of thousands of copies to return even a marginal profit. $^{67}$

The anticipation of these retail networks had a direct impact upon the design of Lane's new paperbacks. While the books themselves proudly embraced the mechanics of mass production, it was culturally vital that these dynamics did not extend to the texts printed inside. During the 1930s, the reading tastes of the British working classes became the subject of sustained critique. The content and appearance of bookstall "novelettes" and the thrillers and romances in twopenny libraries caused

\footnotetext{
${ }^{62}$ Nickianne Moody, "Fashionable Design and Good Service: The Spinster Librarians at Boots Booklovers Library," in Gendering Library History, ed. Evelyn Kerslake and Nickianne Moody (Liverpool, 2000), 131-44.

${ }^{63}$ Christopher Hilliard, "The Twopenny Library: The Book Trade, Working-Class Readers, and 'Middlebrow' Novels in Britain, 1930-42," Twentieth Century British History 25, no. 2 (June 2014): 199-220; James, Popular Culture and Working-Class Taste in Britain, 27-28.

${ }^{64}$ Nicholas Joicey, "A Paperback Guide to Progress: Penguin Books 1935-c.1951," Twentieth Century British History 4, no. 1 (January 1993): 25-56; Lewis, Penguin Special, 89-91, 98-100; McCleery, "The Return of the Publisher to Book History," 161-85.

${ }^{65}$ Allen Lane, "All about the Penguin Books," Bookseller, 22 May 1935: 497.

${ }^{66}$ Lewis, Penguin Special, 99-100; McCleery, "Return of the Publisher," 168. See also Paul Seaton, $A$ Sixpenny Romance: Celebrating a Century of Value at Wolworths (London, 2009), 73.

67 There is some dispute about the number of sales needed to recover production costs. In 1937, the packaging journal Shelf Appeal set the figure at between fourteen thousand and fifteen thousand. Jeremy Lewis, drawing on Penguin's own publicity, sets the figure at fifty thousand. See "9,000,000 CryptHatched Penguins," Shelf Appeal (August 1937): 48-52, at 48; Lewis, Penguin Special, 106.
} 
commentators from both sides of the political spectrum to publicly infer their deleterious effects. ${ }^{68}$ Such cheaply produced volumes were notorious for their small and blurry type, their low-grade paper, and the sensational cover art that advertised to browsers the salacious thrills inside. To middle-class observers, these were faithful signifiers of an internal dearth of literary value. Young's production design for Penguin thus sought to distance the new paperbacks from such disreputable fare, even as they sought to enter the same marketplace. Not only was a Penguin's internal text uncommonly legible and its paper nonabsorbent, but the color-coded covers-heavily modeled on the Albatross series-appeared modern, functional, and dispassionately sober. ${ }^{69}$

The Penguins were, Lane claimed, "the first serious attempt at introducing 'branded goods' to the book trade."70 This boast is misleading, for cheap series of hardback reprints, such as Collins' Classics, Nelson's Classics, and the Everyman's Library, had been available in bookshops from almost the turn of the century. Volumes of the Everyman's Library, for instance, had shared an elegant Arts-andCrafts-style dust jacket since 1906, and at 2s. 6d. were keenly marketed at working-class autodidacts eager to establish a personal collection. ${ }^{71}$ Yet in aligning his Penguins with Woolworth's nascent self-service culture rather than with the expertise of professional booksellers, Lane had to ensure that the outward design of his paperbacks worked harder than their predecessors to signal the value of an unfamiliar text inside. In addition, Penguins needed to be purchased with a comparative lack of calculation and forethought. When Lane famously remarked that they were "something that could be bought as easily and as casually as a packet of cigarettes," he was describing a requirement of the firm's industrial model, which relied on a buying style more characteristic of household groceries than important works of fiction. ${ }^{72}$ Penguin's branded packaging was a vital facilitator, for it subsumed each volume into a greater set of visibly significant literature. Until around 1940, the books even lacked a cover blurb to summarize their contents. With only a title and the author's name in modish Gill Sans, the browser was left to rely on the legend "PENGUIN BOOKs" and the eponymous colophon as evident hallmarks of quality. On the back they found only a list of other Penguins, again privileging the branded series as a vehicle of consumer trust.

This semiotic structure was further reinforced by the way in which the books were put on sale. New Penguin titles were always released in batches of ten, and the standard minimum order was ten copies of each. Lane hoped that upon receiving delivery of these hundred or so books, retailers would be so eager to shift their stock that they would create a dedicated Penguin Books display. ${ }^{73}$ Large accumulations of a single

\footnotetext{
${ }^{68}$ Steve Chibnall, "Pulp versus Penguins: Paperbacks Go to War," in War Culture: Social Change and Changing Experience in World War Two, ed. Pat Kirkham and David Thoms (London, 1995), 131-149, at 132; Christopher Hilliard, "Popular Reading and Social Investigation in Britain, 1850s-1940s," Historical Journal 57, no. 1 (March 2014): 247-71; James, Popular Culture and Working-Class Taste in Britain, $47-53,66-78$.

${ }^{69}$ Baines, Penguin by Design, 13, 18-23; Hare, "Creation Myths."

${ }^{70}$ Lane, "Penguins and Pelicans," 42.

${ }^{71}$ Feely, "Karl Marx, Capital, and Radical Book Cultures in Britain," 123-30.

72 Lane, "Penguins and Pelicans," 42; my emphasis.

73 "The Surprising Story of the 'Penguins," Recorder, 1 February 1947, in Scrapbook (1930-1954), DM1294/1/3, Penguin Archive, University of Bristol Library Special Collections.
} 
branded commodity were a common sight within high-street multiple stores in 1935, but they were virtually unknown inside bookshops. Once the popularity of the series became clear, however, most booksellers relented and displayed all their Penguins together instead of integrating them with the rest of their merchandise. In November 1937, Lane even refused a stand at the National Book Fair on the grounds that, unlike the output of his publishing rivals, presentations of the entire Penguin range were so familiar that they did not need replication in a commercial exhibition. ${ }^{74}$

This display technique was fundamental to Penguin's success, both as a capitalist enterprise and as a social-democratic project. By borrowing the aesthetics of branded mass consumption, the assembled books were able to articulate a particularly potent consumer address. In 1939, bookseller W. E. Hill celebrated the "relative pulling power and advertising value" of displaying one's Penguins all in one place. Many of his customers, he wrote, would never think of buying a hardback for themselves and only came into his shop to purchase a present for somebody else. But once through the door, the clustered Penguins exerted a strange appeal: "Customers paying accounts, coming in for stationery, educational publications, or general literature, are attracted by the brightness of the jackets; they pause, linger, and then they buy one or two copies. That is not forced selling, but something which the customer has found for himself and, what is more, is pleased to find." 75

In 1938, this process was recorded in more detail by a volunteer Mass-Observer, who spent a Saturday afternoon covertly watching browsers outside the bookshops on London's Charing Cross Road:

2.21 p.m. At Foyle's Penguin Window g25 lower middle-class, medium-small, shabby coat.

2.21.10 Picks up 3 Pelican books Freud - 'Totem and Taboo' Virginia Woolf - 'The Common Reader'

G. D. H. Cole - 'Practical Economics'

2.21.10-20 Holds three in her left hand and stares up into the top of the window.

2.21.20 Puts them all down and then picks up the Virginia Woolf.

2.21.25 Goes into shop and gives cashier 6d for book.

2.21.55 Comes out and walks towards Tottenham Ct. Rd. ${ }^{76}$

From start to finish, this operation took barely fifty-five seconds-a remarkably short time in which to select three diverse titles, decide to purchase one of them, and then complete the transaction. The browser under surveillance was notably uninterested in the contents of her Penguins. It is highly possible that she had already read about them in her copy of Penguin's Progress and came to Foyles's window with a shopping list in mind. But she might equally have displayed that same spontaneous self-selection described by Hill, a procedure promoted by both the paperbacks' cheapness and the cultural safety net of their branding. Stockpiled together away

74 “The Chill of Uniformity," Bookseller, 24 November 1937, in Scrapbook (1935-9), Penguin Archive.

${ }^{75}$ W. E. Hill, "A Bookseller Defends the Sixpennies: A Paper Read at the Buxton Conference," Bookseller, 16 June 1939: 880-881, at 881 .

${ }^{76}$ Mass-Observation, TC Reading Habits, 20/2/B, MOA. 


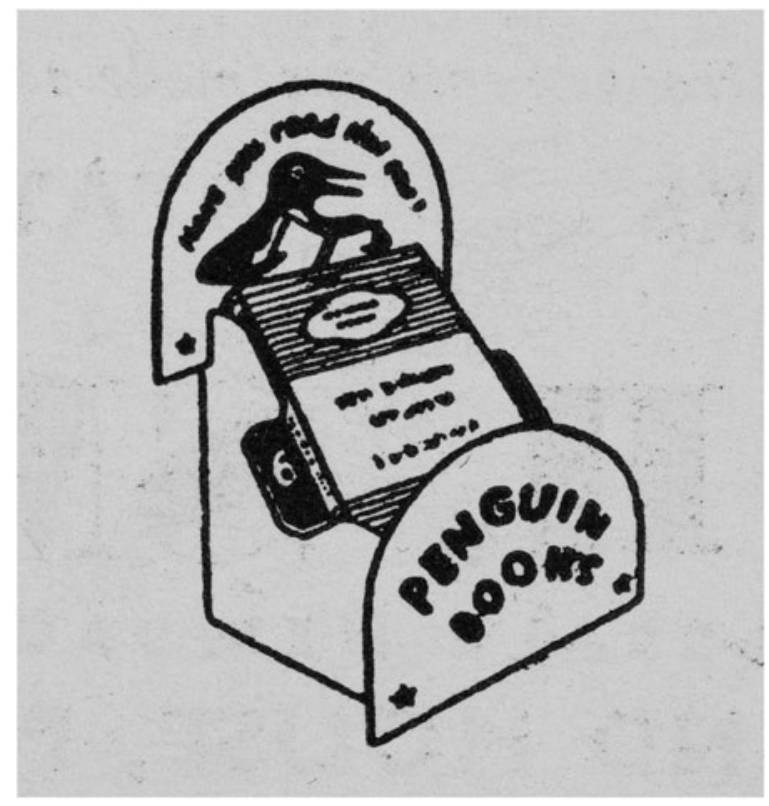

Figure 5-Promotional display cradle for a Penguin paperback (now lost). Detail of trade advertisement for Penguin Books, Bookseller, 20 July 1939, in Scrapbook (1930-1954), DM1294/1/3, Penguin Archive, University of Bristol Library Special Collections.

from the bookseller's gaze, Freud, Woolf, and Cole were visibly marked as equivalents whose similar worth outweighed their differences in theme. Like any other prepackaged, mass-produced commodity, the quality of their contents could be taken on trust; the customer felt no particular need to open each packet and check inside.

The Penguin mascot strengthened this dynamic by embedding it within a narrative of personal transformation. The firm rarely placed advertisements outside of the pages of the bookselling press, so most ordinary Britons only ever encountered the bird at the places where the books were sold. Printed both on book covers and on promotional show cards, the cartoon penguin offered browsers a blueprint for how to understand their relationship to the nearby paperbacks. In 1939, for instance, the mascot featured on a cardboard show-cradle designed to display a chosen volume more prominently on the counter (figure 5). Positioned on the headboard of what resembled a tilted bed, the bird looked up from its unnamed paperback and asked of the browser: "Have you read that one?" This was, of course, exactly the kind of direct bookseller's question that Lane thought would terrorize his target clientele. Yet voiced via the mascot, it became a more friendly inquiry, an impression reinforced by the casual domestic setting. Whichever paperback the retailer displayed became instantly subsumed into the larger brand-"Have you read that one?"-while the daunting terrain of significant literature was reduced to the set of only Penguin Books, a finite series to conquer one volume at a time.

The cradle's most important trope, however, was one that would dominate Penguin's promotional imagery for many years to come: the penguin mascot was shown reading a Penguin paperback, announcing to prospective purchasers that 
they and the bird were of the same species. Following the advertising character's confirmed dynamics, this well-read penguin became an idealized projection of the browser it addressed, returning to guide its earlier self, through the sale of its own products, along the road to literary enlightenment. In the autumn of 1937, when Mass-Observation inquired into the reading habits of its respondents, those who mentioned Penguins or Pelicans often described a more expansive mode of bookbuying detached from their present reading needs. As one twenty-year-old commercial student explained, "I buy a few Penguins (or Pelicans) nearly every time a fresh batch is issued, which is six times a year or so, and have a total of 21 , collected during the 18 months during which they have been on sale." 77 Purchases like these were aligned with the rhythm of the books' industrial production rather than with the respondent's particular pattern of reading. As another confided, "I bought half a dozen [Penguins and Pelicans] by going through the catalogue, early this summer. ... I shall buy more, when I am affluent, or when I find one has been added which I must have."78

These testimonies record an important shift in how books were bought, or even borrowed. No longer a remedy for an immediate lack of something to read, they became bound up in a more aspirational mode of acquisition. The Penguins' low cover price and brand reassurance allowed customers to buy paperbacks not only for themselves but for some idealized version of who they might become. One thirty-five-year-old woman wrote that, despite her disciplined approach to buying hardbacks (of which she only bought titles she had previously read and therefore knew she liked), she habitually bought Penguins and Pelicans "on spec." These were on topics that she was "not normally interested in, or on which I would like at some time to remedy my complete ignorance."79 As another respondent succinctly put it, "I buy all the Pelicans and other 6d. [reprints] if I only imagine I want them." 80 In 1939, one bookseller reported selling twenty-six different Penguin titles to the same customer, all for his own personal reading. ${ }^{81}$ Lane's embrace of mass production thus altered his paperback's center of gravity, away from the hours of its final consumption and toward the preliminary moment of its purchase. Individuals of limited means could now craft-through their shopping, more than their reading - an imagined, more enlightened future self. Perhaps unsurprisingly, Mass-Observation found in 1947 that almost a third of middle-class Penguin readers had yet to read all the paperbacks on their shelves. ${ }^{82}$

Most crucially, the Penguin mascot embedded these individual self-transformations within a vision of collective empowerment. This was made clear, for instance, by the firm's "Summer Sales Drive" in 1936, which awarded cash prizes to the retailers that submitted the best photographs of a Penguin Books-themed window display. ${ }^{83}$

\footnotetext{
77 Mass-Observation, TC Reading Habits, 20/1/D, response no. 4, MOA.

${ }^{78}$ Ibid., response no. 33.

${ }^{79}$ Cited in Mass-Observation, "Books and the Public," February 1944, FR 2018, p. 135, MOA; my emphasis.

${ }^{80}$ Mass-Observation, "Penguins," 1937, TC Reading Habits, 20/1/A, p. 1, MOA.

81 "Petrel" (bookseller), cited in Hill, "A Bookseller Defends the Sixpennies," 880.

${ }^{82}$ Mass-Observation, "Report on Penguin World," 98.

83 "Prizes for Penguins," Bookseller, 8 April 1936, 352; "Make Hay While the Sun Shines: Penguin's Great Summer Sales Drive" (advertisement), National Newsagent, Bookseller and Stationer, 23 May 1936, 1. Window-dressing competitions by mass manufacturers had been common since before the
} 
To aid their efforts, booksellers could request a promotional pack that included colored streamers, window-frame stickers, and a set of five show cards-one for each of the color-coded genres into which Penguin paperbacks were divided. Each show card presented the company's mascot in a different thematic guise. The "History" penguin, for instance, wore a university mortarboard and pointed with its flipper to a country on the globe; the "Mystery \& Crime" penguin borrowed Sherlock Holmes's cape and deerstalker and carried a magnifying glass and pipe; the "Fiction" penguin (the important first instance of a penguin reading a Penguin) relaxed in a well-stuffed armchair, an open novel between its flippers. On its own, each mascot proffered an attractive image of the greater self that these books might help produce; a History Penguin would make one more scholarly, a Mystery Penguin, more deductive, and so on. But the suite of five show cards was designed to be shown together as a heterogeneous, yet harmonious colony. So displayed, they conjured an image of Penguin's diverse and progressive readership, for which they now stood as both metaphor and synecdoche.

These dynamics were confirmed the following summer by another set of in-store show cards, two of which notably depicted a coterie of mascots at play around an oversize book. In "Make Holiday with Penguin Books," Henry Williamson's Tarka the Otter had become a floating pontoon from which the cartoon penguins leapt in and swam. In "Penguins Launch Pelican Books," Shaw's inaugural The Intelligent Woman's Guide to Socialism and Capitalism was a giant raft that the birds pushed into the sea. ${ }^{84}$ In the sole surviving image of these show cards, the text in the mascots' speech bubbles is too obscure to read, but both clearly positioned their volume at the literal center of the birds' conversation. They thus imagined Penguin's readership as an active and dialogic public sphere, framing the nearby stacks of books as the connective tissue that sustained a network of engaged debate-even if many of those actual paperbacks would never be discussed and might not even be read.

The mascots' ability to project this imagined public surely explains why Coles's suggestion was unanimously accepted as an obvious stroke of genius. In 1934, the year before that decisive conference, Berthold Lubetkin's fiercely modernist Penguin Pond had opened at London Zoo (figure 6). Ovoid in form and consciously eschewing any pretence at a naturalistic backdrop, this geometric structure was designed to communicate the zoo's enlightened stewardship of its exotic animal charges. In stark contrast to the haphazard contingency of their Antarctic home, the Penguin Pond conspicuously reveled in its controlled and expert sensitivity to the birds' physiological and social needs-right down to the alternation of concrete, rubber, and slate flooring to correctly stimulate their feet. ${ }^{85}$ Against the visual disorder of the rest of the zoo, with its irregular plantings and historic mishmash of animal houses, Lubetkin's egg-shaped compound declared itself to be an holistic penguin

\footnotetext{
First World War. They focused customers' attention on the product and, when the winning photographs were published, provided templates for other shopkeepers to emulate. See Susan Lomax, "The View from the Shop: Window Display, the Shopper and the Formulation of Theory," in Cultures of Selling: Perspectives on Consumption and Society since 1700, ed. John Benson and Laura Ugolini (Aldershot, 2006), 265-291, at 271 .

84 "9,000,000 Crypt-Hatched Penguins," 52.

${ }^{85}$ Jonathan Burt, "Violent Health and the Moving Image: The London Zoo and Monkey Hill," in Animals in Human History: The Mirror of Nature and Culture, ed. Mary Henniger-Voss (Rochester, 2002), 258-92.
} 


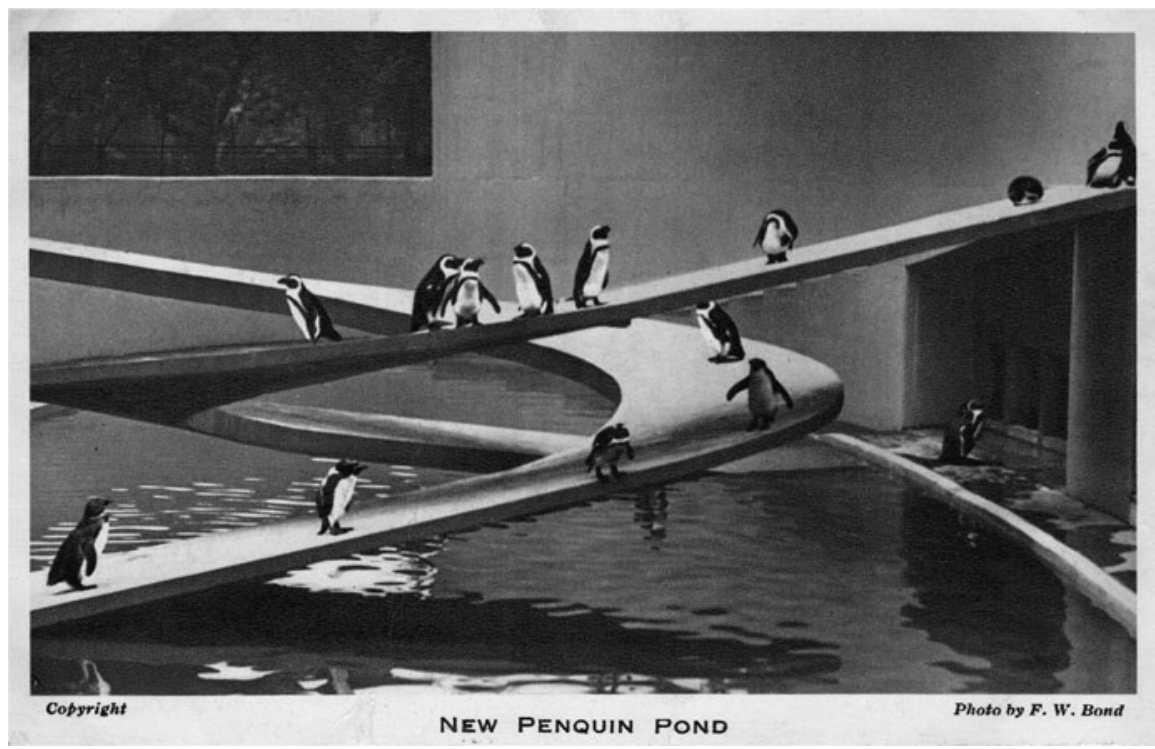

Figure 6-The Penguin Pond at London Zoo. Postcard, c. 1934. Author's collection.

utopia. ${ }^{86}$ It aimed to teach human spectators about the transformative power of scientific architecture, for if they connected its startling appearance to the obvious wellbeing of its tenants, then they might understand how modernist buildings could increase the health and happiness of human communities too. ${ }^{87}$ This desired correspondence was made more plausible by the birds' basic physiology. As flightless bipeds, their inelegant shuffle around the pond provoked a range of anthropomorphic media analogies, including soldiers on parade, "Dominicans in feathers," and "self-conscious chorus girls on a cjoy plank." 88

The great popular interest in London's new Penguin Pond made Coles's suggestion of a penguin mascot timely as well as appropriate. Lubetkin's enclosure and Lane's paperbacks both sought to project an image of a progressive and cohesive human society, and each deployed a colony of penguins as a demonstrative analogy. They shared the same paternalistic faith in the authority of experts-be they architects, biologists, or literary editors-which soon led to several leading

${ }^{86}$ John Allan, Berthold Lubetkin: Architecture and the Tradition of Progress (London, 2012), 142. See also Hadas A. Steiner, "For the Birds," Grey Room 13 (Fall 2003): 5-31.

${ }^{87}$ Allan, Berthold Lubetkin, esp. 134-35; Peder Anker, "The Bauhaus of Nature," Modernism/Modernity 12, no. 2 (April 2005): 229-51; Pyrs Gruffudd, "Biological Cultivation: Lubetkin's Modernism at London Zoo in the 1930s," in Animal Spaces, Beastly Places: New Geographies of Animal-Human Relations, ed. Chris Philo and Chris Wilbert (London, 2000), 223-41.

88 "Picture Gallery: The Penguins on Parade," Daily Mail, 8 December 1935, 16; "A'Blue-Water School' of Penguins: The New 'Zoo' Pond,” Illustrated London News, 30 June 1934, 1061; “15 O’Clock Is Feeding Time," Daily Mirror (London), 26 May 1934, 13. For a longer history of penguin anthropomorphism, see Stephen Martin, Penguin (London, 2009). 


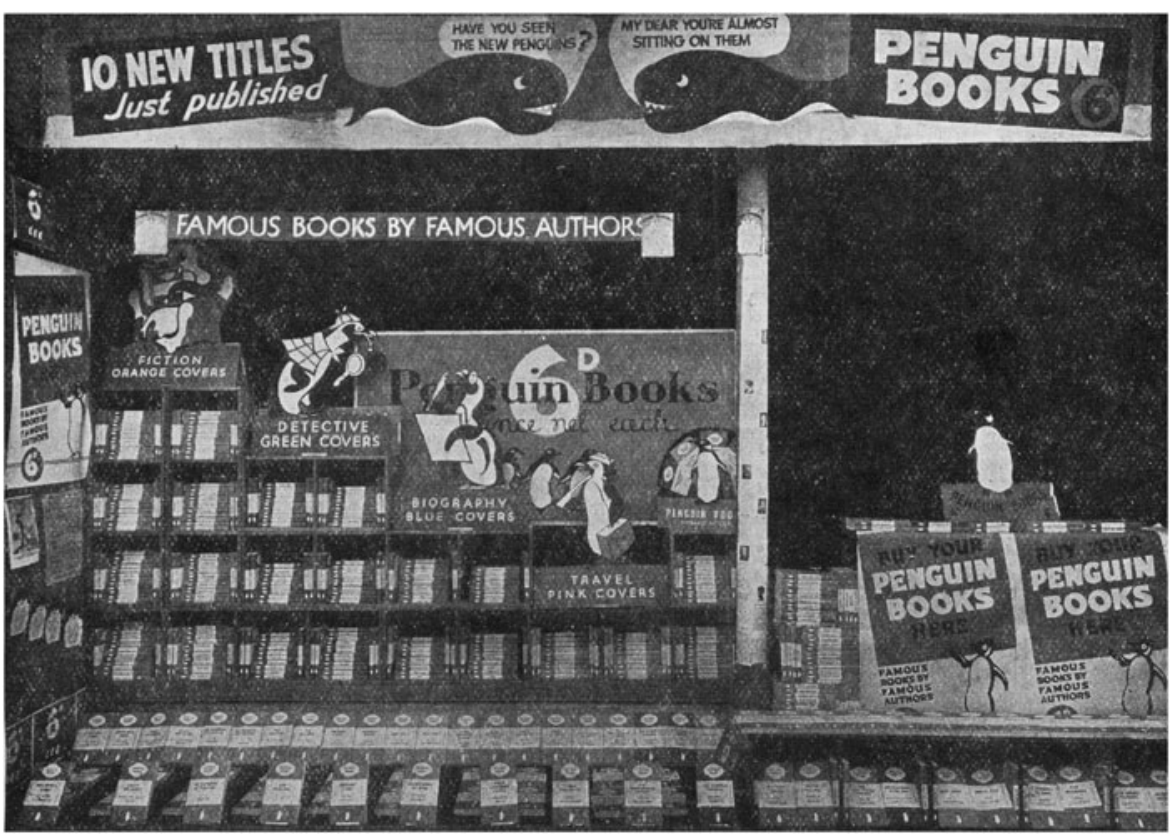

Figure 7-Window of the Student's Bookshop, Tottenham Court Road, London. Taken from Bookseller, 19 April 1937, in Scrapbook (1935-9), DM1294/1/1, Penguin Archive, University of Bristol Library Special Collections.

Zoo personnel becoming actively involved in the Penguin Books project. ${ }^{89}$ In 1937 , when Lane was planning a modern new distribution center out at Harmondsworth in Middlesex, he even asked Lubetkin to replicate his Penguin Pond on the forecourt. At night, Lane hoped, the floodlit birds inside would catch the eyes of passing motorists on the arterial road to Bath. ${ }^{90}$

Surviving photographs of dedicated Penguin Books displays show a veritable profusion of cartoon mascots, as the larger birds on the company's show cards are echoed by many smaller colophons on the adjacent books (figure 7). Each paperback cover featured the penguin three times - once on the front, once on the back, and once on the spine-so whichever way the book was shelved, an image of the bird was visible. To encounter a pile of Penguins in the shop was always to be greeted by at least as many penguins, a fact that seems to have significantly altered the relationship of

${ }^{89}$ In 1937, Sir Peter Chalmers Mitchell (who, as secretary of the Zoological Society of London, had commissioned Lubetkin's Penguin Pond) briefly served as an advisory editor for the new Pelican series. In 1940, Penguin reprinted his monograph, The Childhood of Animals. Chalmers Mitchell's successor at the Zoo, Julian Huxley, also contributed one of the earliest Pelicans with his Essays in Popular Science (London, 1937).

${ }^{90}$ Lubetkin recounts this story (and his refusal) in Allan, Berthold Lubetkin, 249. Press reports frequently mentioned Lane's plans for a penguin pond, although they refrained from mentioning London Zoo by name. See News Chronicle (London), 7 October 1937; "Real Romance: How the Penguins Came to Harmondsworth," Middlesex Advertiser, 19 November 1937; “A Book Warehouse,” Builder, 25 March 1938. 


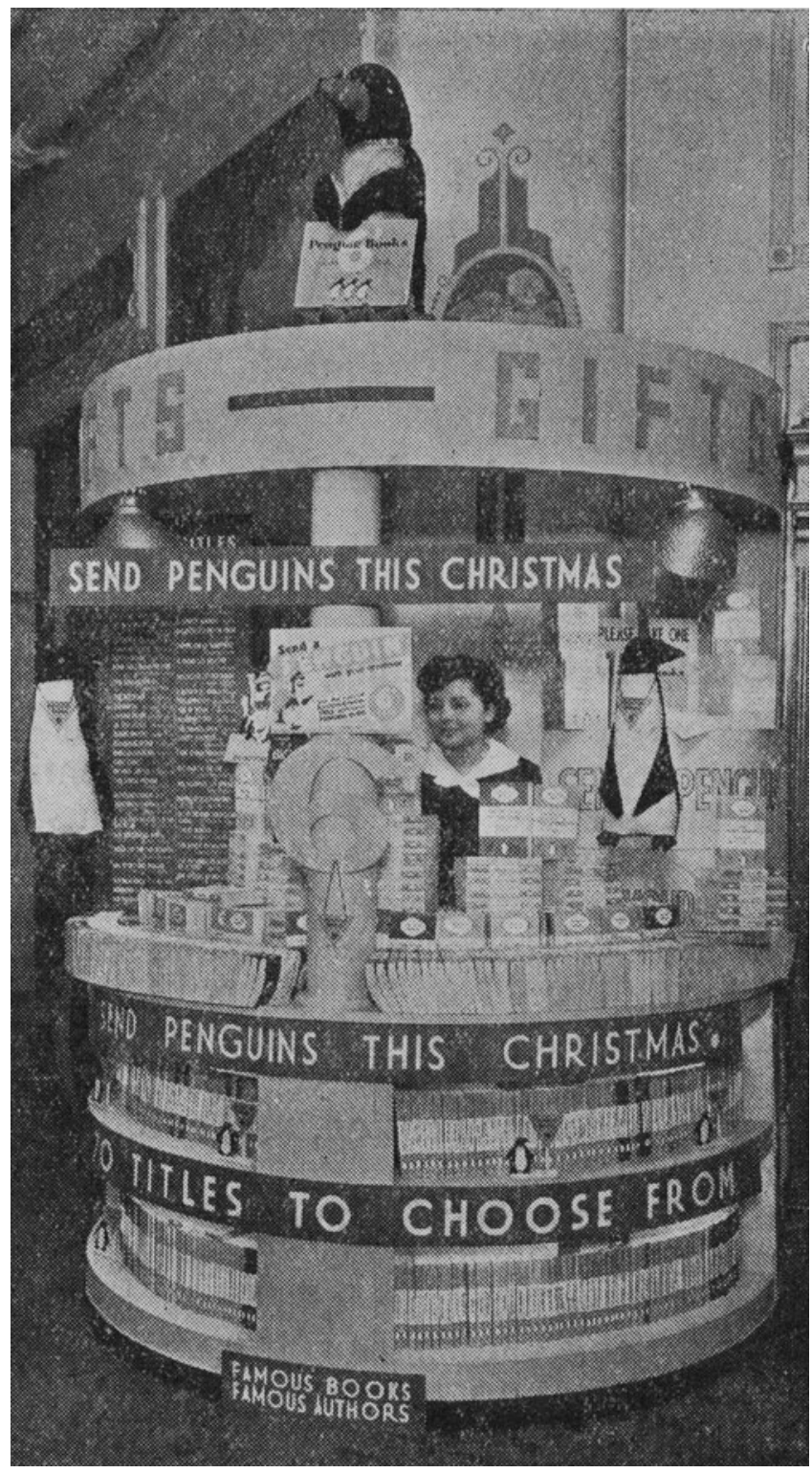

Figure 8-Penguin Books sales kiosk, Whiteley's department store, London, 1936. Taken from Bookseller, 9 December 1936, in Scrapbook (1935-9), DM1294/1/1, Penguin Archive, University of Bristol Library Special Collections.

the browser to the books on show. In a conventional bookshop, the primacy accorded to the author's name or the book's central theme led to the intermingling of stock from different publishing houses on the shelf, as each firm's output was distributed across the store. Most ordinary bookshelves thus proposed a set of discrete one-toone relationships between each component volume and the peruser who might 
wish to read it. A Penguin display, in contrast, drew shoppers' attention to the larger aggregate readership among whom its paperbacks would soon become dispersed. Given the semantic slippage between mascot and consumer, this colony of penguins served as a barely displaced vision of the progressive mass public for whom it now stood in, and to which it pointed the way. To select a paperback from the display and take it over to the cash desk was, on some level, already to claim one's place within this future cultural democracy-to become in effect the penguin on the cover-regardless of what happened to that book after one left the store.

\section{CONCLUSION}

We can only speculate whether Mr. Burke, the manager of the Book Department in Whiteley's department store in London, sought to evoke Lubetkin's recent Penguin Pond when he created a Penguin sales kiosk in 1936 (figure 8). Originally located on the building's top floor between the restaurant and the customer lift, it was soon moved down to the busier ground level in order to maximize the passing Christmas trade. ${ }^{91}$ Segregated from the rest of Whiteley's book stock and centripetally detached from its immediate surroundings, Burke's rotunda expressed the same urge toward holistic self-sufficiency as the penguin enclosure at London Zoo. The real birds in Regent's Park might have become replaced by a myriad of colophons, cartoon show cards and the occasional plush toy, but in gaining a new mobility on the backs of posted paperbacks, this colony could broadcast its progressive vision more effectively throughout the country.

In a 1942 report on "Books and the Public," Mass-Observation quoted an interviewee: "I think it is the attractiveness of Penguin and Pelican books in their form which always makes me stop and look at any display of them, to see if there are any new titles I want. Certainly I do not feel drawn in the same way to other cheap books. And I not infrequently buy books which I had not at all intended to get, simply because their appearance has made me stop and look." "92 Five years later, in the tellingly titled "A Report on Penguin World," the same organization found that response to be typical: "In the process of buying on sight, the distinctive covering of Penguin books, and the bookseller and newsagent practice of keeping them all together, probably has considerable influence. Many people describe how when they enter a bookshop, they make for the shelves containing these books. The 'piles of Penguins' and the neat, orderly rows give people a good deal of pleasure, and it is possible that this pleasure influences them to buy." 93

Mass-Observation did not speculate about the source of this pleasure or about why an inert pile of mass-produced paperbacks should exert such an affective pull. But in appropriating the retail aesthetics of mass consumption, Penguin was able to rework a strand of interwar cultural optimism about branded goods as a harbinger of material democracy. In Britain in the mid-1930s, any pile of mass-produced commodities had the potential to evoke social parity and empowerment through the imagined

${ }^{91}$ Bookseller, 9 December 1936, in Scrapbook (1935-9), Penguin Archive.

92 Mass-Observation, "Books and the Public," July 1942, 145-46, FR 1332, MOA; emphasis in the original.

93 Mass-Observation, "Report on Penguin World," 91, MOA. 
franchise of the new mass market. Such meanings were already implicit within uniform packaging, affordable prices, and nationwide distribution and advertising. But it was left to brand mascots, as new mass-media figures, to encourage viewers to imagine themselves within their projected consumer-electorate.

In appropriating these meanings, the Penguin mascot sutured its mass-produced paperbacks into a utopian vision of modern social progress. Detached from their prototypes at London Zoo and distributed widely across Britain's bookstalls and multiple stores, Young's cartoon birds performed a hybrid left-wing salesmanship and promoted an optimistic social-democratic consumerism. Penguin's dual embrace of mass production and chain-store distribution always achieved more than just increasing the number of people who could access and read these works. Through the books' cover design and their arrangement on the shelf, the ordinary act of buying a Penguin paperback became an everyday act of initiation into a new type of cultural democracy. These preliminary moments of browsing and exchange were vital in shaping the subsequent meaning of the books, right up to their reading and collation within the home. If Penguin Books promised to induct its readers into a modern, mass-market public sphere, then this offer was primarily made by its cartoon mascots in the shops. 